\title{
ANALISIS POTENSI EKONOMI SEKTORAL KORIDOR UTARA SELATAN PROPINSI JAWA TIMUR TAHUN 2005 - 2009
}

\author{
Oleh: \\ M. Sofyan Andiatma \\ Fakultas Ekonomi dan Bisnis Universitas Muhammadiyah Malang
}

\begin{abstract}
The research analyzes main sector, contribution of each sector and economic growth pattern in Regency / City North-South Corridor of East Java Province year 2005-2009. Research method used is Location Quentiont (LQ) analysis, contribution analysis, and Klassen typology analysis. The research uses Location Quentiont (LQ) analysis tool which is sector with the largest superiority, which are electricity, gas, and clean water in Gresik regency and sector with the smallest superiority which are farm, mining, and excavation in Mojokerto City, according to contribution analysis of trading, hotel, and restaurant in Batu city gave the biggest contribution, which is $51.72 \%$ according to Klassen typology analysis of Regency / city with fast and growth economic development is Surabaya and Mojokerto. Rapid development is Pasuruan regency, Blitar regency, batu city, Pasuruan, Blitar. Developed and pressed are Gresik regency, Sidoarjo regency, and Malang City. The one with left economic growth are Mojokerto regency and Malang regency. According to the analysis done, it needs role from all communities, especially government to pay attention, montitor, and develop all main potential in Regency / City in North-South Corridor of East Java.
\end{abstract}

Keywords: Location Analysis, Analysis of Contributions, Typology Klassen, East Java corridor

\begin{abstract}
ABSTRAK
Penelitian ini menganalisis sektor utama, kontribusi masing-masing pertumbuhan ekonomi sektor dan pola di Kabupaten / Kota Utara-Selatan Koridor Provinsi Jawa Timur tahun 2005-2009. Metode penelitian yang digunakan adalah Analisis Lokasi (LQ), analisis kontribusi, dan analisis tipologi Klassen. Penelitian ini menggunakan Lokasi Quentiont (LQ) alat analisis yang sektor dengan keunggulan terbesar, yang listrik, gas, dan air bersih di Kabupaten Gresik dan sektor dengan keunggulan terkecil yang pertanian, pertambangan, dan penggalian di Kota Mojokerto, menurut analisis kontribusi dari perdagangan, hotel, dan restoran di kota Batu memberikan kontribusi terbesar, yang 51,72\% menurut Klassen analisis tipologi Kabupaten / kota dengan perkembangan cepat dan pertumbuhan ekonomi Surabaya dan Mojokerto. perkembangan pesat adalah Kabupaten Pasuruan, Kabupaten Blitar, kota batu, Pasuruan, Blitar. Dikembangkan dan ditekan adalah Kabupaten Gresik, Kabupaten Sidoarjo, dan Kota Malang. Yang satu dengan pertumbuhan ekonomi kiri adalah Kabupaten Mojokerto dan Kabupaten Malang. Menurut analisis yang dilakukan, perlu peran dari semua masyarakat, terutama pemerintah untuk memperhatikan, montitor, dan mengembangkan seluruh potensi utama di Kabupaten / Kota di Koridor Jawa Timur.
\end{abstract}

Kata Kunci : Analisis Lokasi, Analisis Kontribusi, Tipologi Klassen, koridor Jawa Timur 


\section{PENDAHULUAN}

Pembangunan nasional saat ini telah dihadapkan pada banyak tantangan yaitu tantangan pertama berkaitan dengan kondisi eksternal seperti perkembangan internasional yang berhubungan dengan liberalisasi arus investasi dan perdagangan global. Sedangkan yang kedua bersifat internal, yaitu yang berkaitan dengan perubahan kondisi makro maupun mikro dalam negeri yang meliputi transformasi struktur ekonomi, masalah migrasi spasial dan sektoral, ketahanan pangan, masalah ketersediaan lahan pertanian, masalah investasi dan permodalan, masalah ilmu pengetahuan dan teknologi (IPTEK), sumber daya manusia (SDM), dan lingkungan.

Menurut Kunarjo (1997:29-55) pembangunan adalah suatu yang dinamis dan berkelanjutan seiring dengan perkembangan setiap aspek kehidupan masyarakat.

Pembangunan nasional adalah usaha peningkatan kualitas manusia dan masyarakat Indonesia yang dilakukan secara berlanjut, berlandaskan kemampuan nasional, dengan memanfaatkan kemajuan ilmu pengetahuan dan teknologi serta memperhatikan tantangan perkembangan global. Tujuan pembangunan nasional adalah untuk membangun tatanan kehidupan bermasyarakat, berbangsa dan bernegara serta mewujudkan kemajuan disegala bidang terutama bidang ekonomi.

Dalam hal ini pemerintah daerah di Indonesia telah mengalami perubahan seiring dengan diberlakukanya otonomi daerah, dengan mendekatkan pembuatan keputusan ke daerah. Undangundang No. 32 tahun 2004 tentang perubahan atas Undang-undang No. 22 tahun 1999 tentang otonomi daerah, telah menyebabkan pergeseran dalam pembangunan ekonomi yang bermula bersifat sentralis, mengarah pada desentralisasi, yaitu dengan memberikan keleluasaan kepada daerah untuk membangun wilayahnya termasuk dalam bidang ekonominya.

Pemberlakuan otonomi daerah juga berarti pemerintah daerah harus memiliki rencana ekonomi daerah yang baik untuk menyediakan kesejahteraan bagi penduduknya. Hal 
ini akan membawa angin segar bagi daerah untuk dapat menggali dan mengembangkan potensi ekonomi secara mandiri sehingga ketimpangan antar penduduk, antar daerah dan antar sektor secara bertahap dapat diperkecil.

Arsyad (2004:13) mengartikan pertumbuhan ekonomi sebagai kenaikan produk domestik bruto tanpa memandang apakah kenaikan itu lebih besar atau lebih kecil dari tingkat pertumbuhan penduduk, atau apakah pertumbuhan ekonomi terjadi atau tidak. Mengingat pentingnya pertumbuhan ekonomi regional, maka setiap wilayah dituntut mampu mengembangkan potensinnya agar dapat menciptakan keunggulan sektoral daerahnya, ini diharapkan agar sektor yang memiliki keunggulan tersebut akan membawa prospek yang lebih baik untuk dikembangkan, sehingga akan berdampak pada sektor-sektor lain untuk berkembang serta berdampak positif terhadap PDRB (Produk Domestik Regional Bruto) baik secara sektoral maupun perkapita.

Kriteria utama keberhasilan pembangunan daerah adalah bentuk PDRB (Produk Domestik Regional
Bruto) secara sektoral maupun perkapita, oleh karena itu PDRB (Produk Domestik Regional Bruto) secara agregatif menunjukan kemampuan suatu daerah tertentu dalam menghasilkan pendapatan dalam proses produksi daerah yang bersangkutan, Propinsi Jawa Timur sendiri terbagi menjadi 38 Kabupaten/Kota, 29 Kabupaten dan 9 Kota.

Propinsi Jawa Timur terbagi lagi menjadi beberapa koridor yang meliputi Kabupaten/Kota yang ada di Propinsi Jawa Timur, yaitu Koridor Utara Selatan terdiri dari Kabupaten Gresik, Pasuruan, Mojokerto, Sidoarjo, Malang, Blitar, dan Kota Surabaya, Batu, Pasuruan, Mojokerto, Malang, Blitar. Koridor Barat Daya terdiri dari Kabupaten Jombang, Kediri, Tulungagung, Trenggalek, Nganjuk, Madiun, Ponorogo, Pacitan, Magetan, dan Kota Kediri, Madiun. Koridor Timur terdiri dari Kabupaten Probolinggo, Situbondo, Bondowoso, Lumajang, Jember, Banyuwangi, dan Kota Probolinggo. Koridor Utara terdiri dari Kabupaten Lamongan, Tuban, Bojonegoro, Ngawi, Bangkalan, 
Sampang, Pamekasan, Sumenep (http://adln.lib.unair.ac.id).

Masing-masing

koridor

memiliki sembilan sektor ekonomi

yang dapat dikembangkan

potensinya sehingga dapat

memberikan konstribusi terhadap

daerah masing-masing, kontribusi

Koridor Utara Selatan (Kabupaten

Gresik, Pasuruan, Mojokerto,

Sidoarjo, Malang, Blitar, dan Kota

Surabaya, Batu, Pasuruan,

Mojokerto, Malang, Blitar) terhadap perekonomian Jawa Timur sekitar 54\%, Koridor Barat Daya sebesar $22 \%$, Koridor Timur sebesar $12 \%$, dan Koridor Utara sebesar $11 \%$ (Maskan, Ali: 2006). Diantara keempat koridor tersebut yang memiliki pertumbuhan ekonomi paling tinggi adalah Koridor Utara Selatan.

Berdasarkan pembahasan di atas peneliti mengambil inisiatif untuk meneliti sektor ekonomi unggulan, kontribusi sektoral dan pola pertumbuhan ekonomi. Hasil penelitian ini diharapkan dapat bermanfaat bagi pemerintah daerah dalam membuat kebijakan dalam pengalokasian dana pembangunan kepada setiap Kabupaten/Kota sesuai dengan potensi yang dapat dikembangkan.

\section{METODE PENELITIAN}

Penelitian ini mengambil lokasi di Provinsi Jawa Timur Koridor Utara Selatan dengan pertimbangan Kabupaten/Kota dikoridor ini mempunyai potensi yang besar di masing-masing sektor. Ruang lingkup penelitian tentang kontribusi sektor-sektor ekonomi terhadap perekonomian di masingmasing Kabupaten/Kota Koridor Utara Selatan Jawa Timur, tingkat pertumbuhan rata-rata setiap sektor perekonomian Kabupaten/Kota Koridor Utara Selatan Jawa Timur dan sembilan sektor ekonomi yang potensial (sektor unggulan) yang dapat dkembangkan di Kabupaten/Kota Koridor Utara Selatan Jawa Timur. Adapun teknik analisa data pada penelitian ini yaitu Analisis LQ (Location Quotient), Analisis Kontribusi, dan Analisis Tipologi Klassen.

\section{PEMBAHASAN}

Ada tiga kondisi yang dapat dicirikan dari hasil perhitungan dengan metode LQ pada wilayah tertentu. Jika LQ > 1, maka sektor dan sub sektor yang bersangkutan 
disamping dapat memenuhi kebutuhannya sendiri juga memberikan peluang untuk diekspor dan dikatakan sebagai sektor unggulan, jika LQ $<1$, maka sektor dan sub sektor yang bersangkutan tidak cukup untuk memenuhi

kebutuhannya sendiri dan dapat dikatakan sektor bukan unggulan sedangkan jika LQ = 1, maka sektor dan sub sektor yang bersangkutan hanya dapat memenuhi kebutuhan wilayah itu sendiri.

Gambar 1. Peta LQ (Location Quontient) Sektor Pertanian

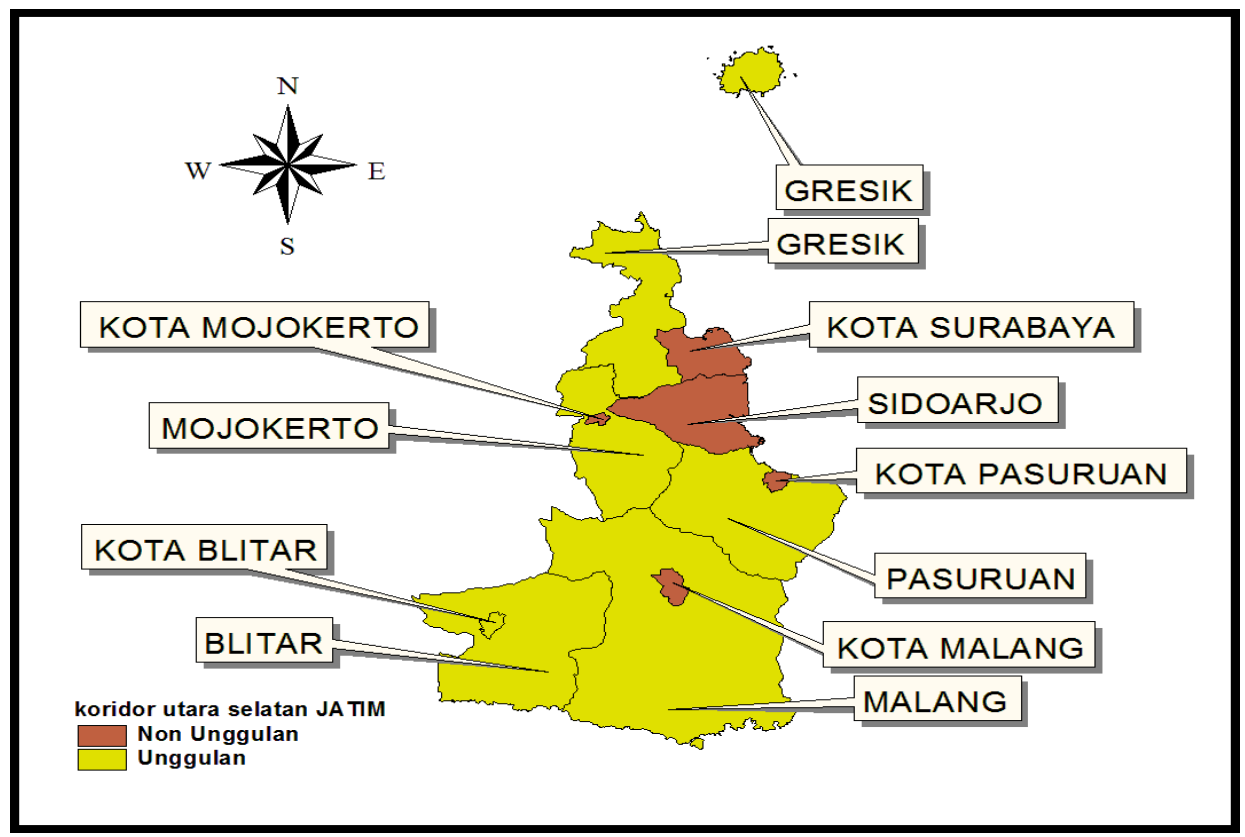

Sumber : Location Quontiet data diolah

Gambar 1, menunjukkan bahwa dengan analisa LQ (Location Quontient) sektor pertanian Kababupaten/Kota Koridor Utara Selatan Propinsi Jawa Timur, menunjukkan bahwa daerah yang memiliki keunggulan dalam sektor pertanian tiga terbesar adalah Kabupaten Blitar (6.60), Kabupaten Malang (3.99), Kabupaten Pasuruan (3.16). Daerah tersebut dapat dinyatakan memiliki keunggulan dalam sektor pertanian atau sektor basis karena daerah tersebut mempunyai nilai LQ lebih besar dari $1(\mathrm{LQ}>1)$.

Sedangkan daerah yang tidak memiliki keunggulan dalam sektor pertanian adalah Kabupaten Sidoarjo (0.51), Kota Surabaya (0.02), Kota Pasuruan (0.63), Kota Mojokerto (0.12) dan Kota Malang (0.07). Hal ini berarti pula bahwa sektor pertanian merupakan suatu sektor 
unggulan daerah di Koridor Utara mendukung pertumbuhan ekonomi Selatan Propinsi Jawa Timur yang koridor tersebut.

dapat terus dikembangkan untuk

\section{Gambar 2. Peta LQ (Location Quontient) Pertambangan dan Penggalian}

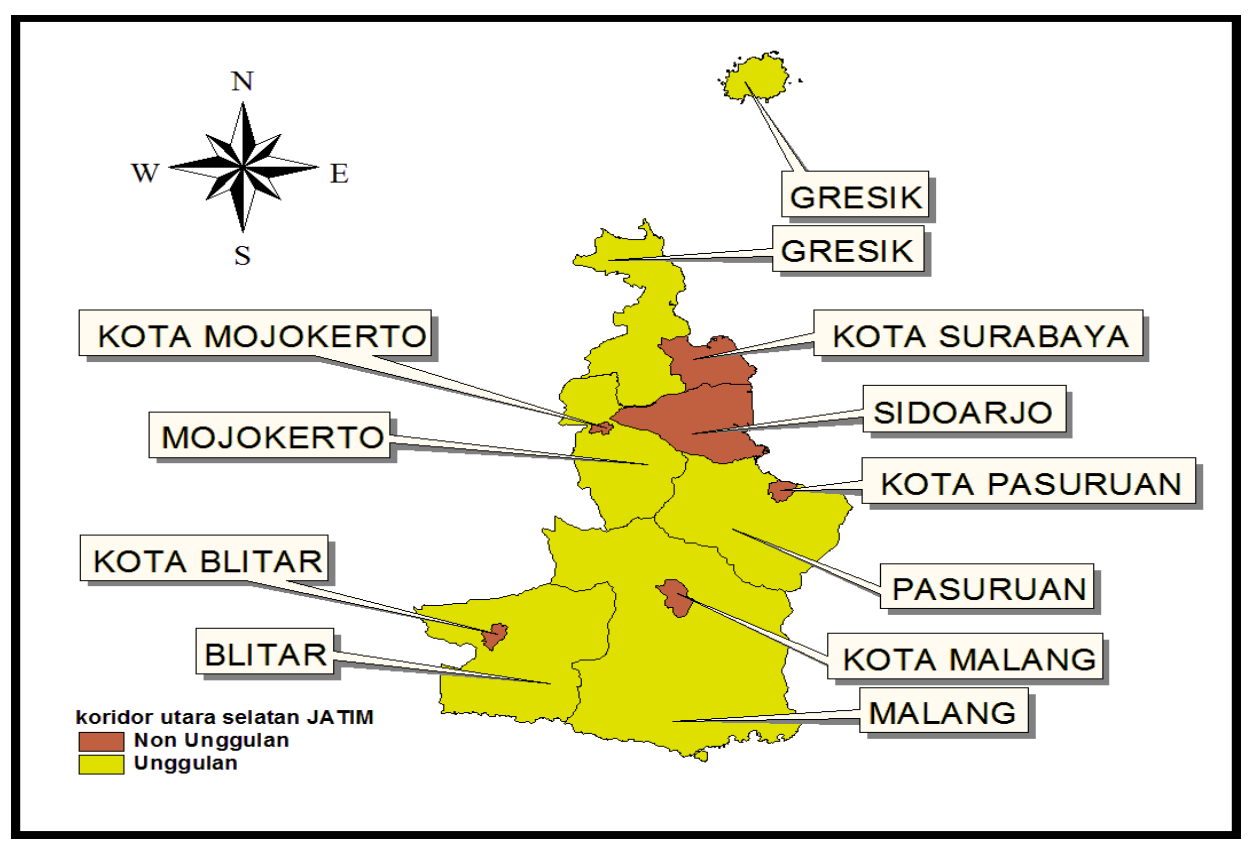

Sumber : Location Quontiet data diolah

Gambar 2 menunjukkan bahwa dengan analisa LQ (Location Quontient) sektor pertambangan dan penggalian Kabupaten/Kota Koridor Utara Selatan Propinsi Jawa Timur, menunjukkan bahwa daerah yang memiliki keunggulan dalam sektor ini adalah Kabupaten Malang (4.55), Kabupaten Blitar (4.33) dan Kabupaten Mojokerto (2.90). Daerah tersebut dapat dinyatakan memiliki keunggulan dalam sektor pertambangan dan penggalian karena daerah tersebut mempunyai nilai LQ lebih besar dari 1 .
Sedangkan daerah yang tidak memiliki keunggulan dalam sektor pertambangan dan penggalian adalah Kabupaten Sidoarjo (0.26), Kota Surabaya (0.02), Kota Batu (0.33), Kota Pasuruan (0.26), Kota Mojokerto (0.00), Kota Malang (0.11), dan Kota Blitar (0.08). Hal ini berarti bahwa sektor pertambangan dan penggalian bukan merupakan suatu sektor unggulan daerah di Koridor Utara Selatan Propinsi Jawa Timur yang dapat terus dikembangkan untuk mendukung pertumbuhan ekonomi koridor tersebut. 
Gambar 3. Peta LQ (Location Quontient) Sektor Industri Pengolahan

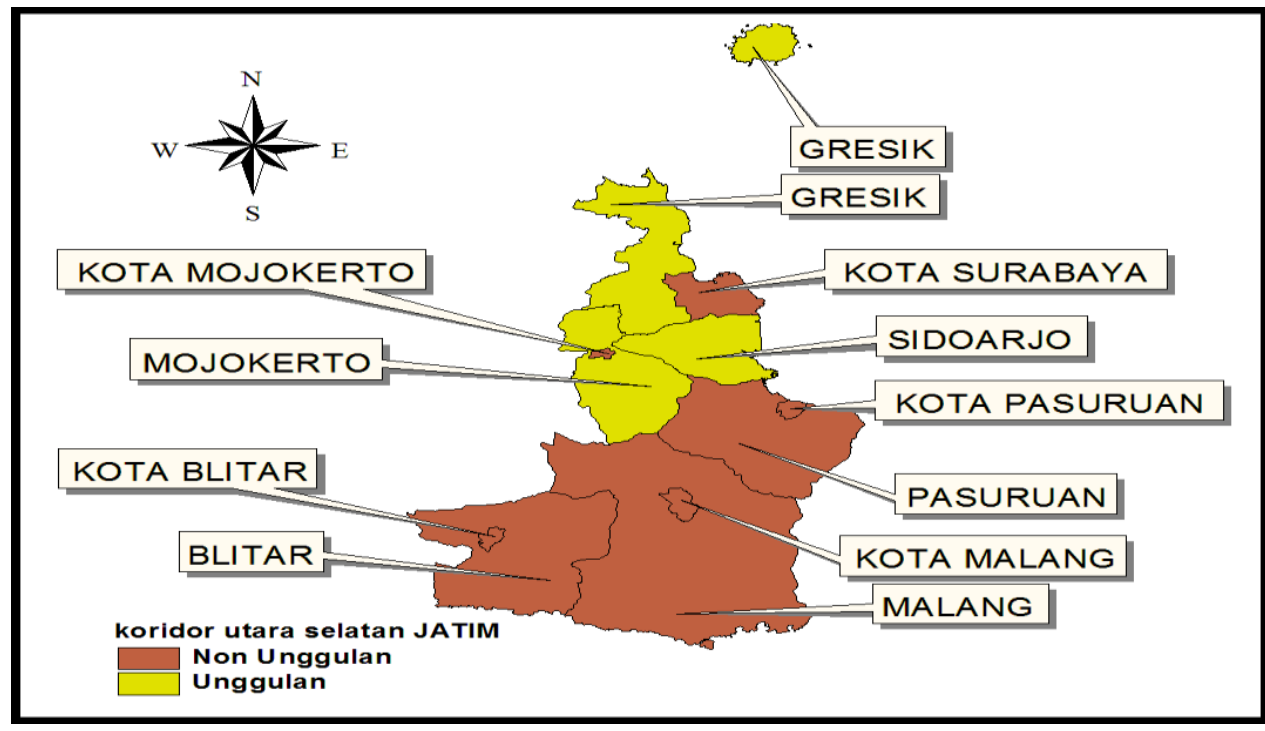

Sumber : Location Quontiet data diolah

Gambar 3 menunjukkan bahwa dengan analisa LQ sektor industri pengolahan Kabupaten/Kota Koridor Utara Selatan Propinsi Jawa Timur, menunjukkan bahwa daerah yang memiliki keunggulan dalam sektor ini adalah Kabupaten Sidoarjo (1.57), Kabupaten Gresik (1.42), Kabupaten Mojokerto (1.10). Daerah tersebut dinyatakan memiliki keunggulan dalam sektor industri pengolahan karena daerah tersebut mempunyai nilai LQ lebih besar dari 1.
Sedangkan daerah yang tidak memiliki keunggulan dalam sektor industri pengolahan adalah Kabupaten Pasuruan (0.99), Kabupaten Malang (0.56), Kabupaten Blitar (0.09), Kota Surabaya (0.90), Kota Batu (0.23), Kota Pasuruan (0.45), Kota Mojokerto (0.43), Kota Malang (0.98) dan Kota Blitar (0.34). Daerah tersebut dapat dinyatakan tidak memiliki keunggulan dalam sektor industri pengolahan karena daerah tersebut mempunyai nilai LQ lebih kecil dari 1. 


\section{Gambar 4. Peta LQ (Location Quontient) Sektor Listrik, Gas dan Air Bersih}

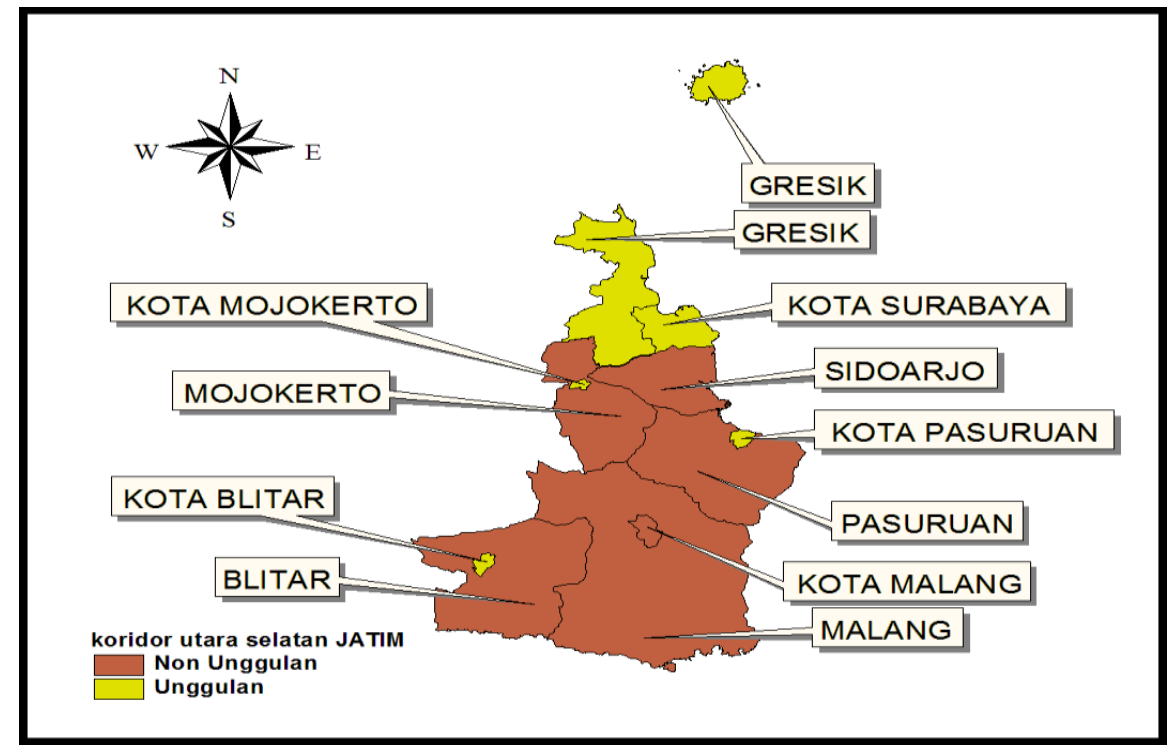

Sumber : Location Quontiet data diolah

Gambar 4 menunjukkan bahwa dengan analisa LQ (Location Quontient) sektor listrik, gas, dan air bersih Kabupaten/Kota Koridor Utara Selatan Propinsi Jawa Timur menunjukkan bahwa daerah yang memiliki keunggulan dalam sektor ini adalah Kabupaten Gresik (2.20), Kota Blitar (1.37), Kota Mojokerto (1.36). Daerah tersebut dinyatakan memiliki keunggulan dalam sektor sektor listrik, gas, dan air bersih karena sektor tersebut mempunyai nilai LQ lebih besar dari 1.
Sedangkan daerah yang tidak memiliki keunggulan dalam sektor sektor listrik, gas, dan air bersih adalah Kabupaten Pasuruan (0.91), Kabupaten Mojokerto (0.44), Kabupaten Sidoarjo (0.77), Kabupaten Malang (0.68), Kabupaten Blitar (0.34), Kota Batu (0.66), Kota Malang (0.16). Daerah tersebut dapat dinyatakan tidak memiliki keunggulan dalam sektor pertambangan dan penggalian karena daerah tersebut mempunyai nilai LQ lebih kecil dari 1.

Gambar 5. Peta LQ (Location Quontient) Sektor Bangunan / Konstruksi

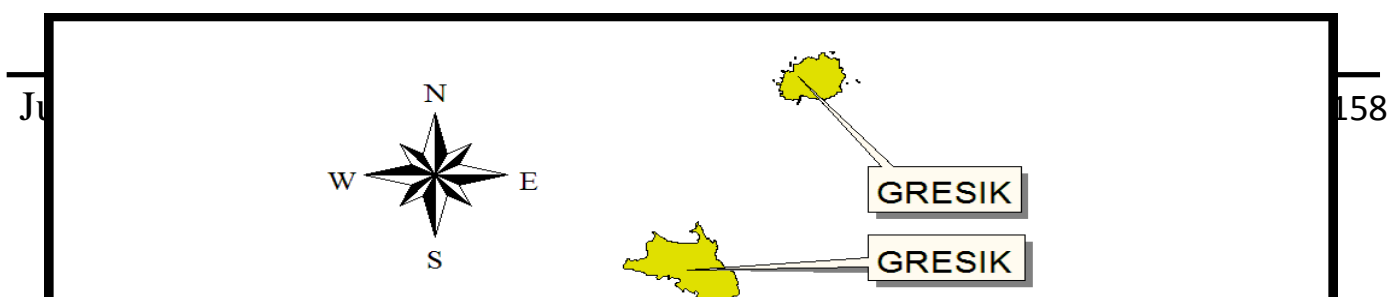




\section{Sumber : Location Quontiet data diolah}

Gambar 5 menunjukkan bahwa dengan analisa LQ (Location Quontient) sektor bangunan/ konstruksi Kabupaten/Kota Koridor Utara Selatan Propinsi Jawa Timur, menunjukkan bahwa daerah yang memiliki keunggulan dalam sektor ini adalah Kota Pasuruan (1.60), Kota Surabaya (1.45), Kota Mojokerto (1.42). Daerah tersebut dapat dinyatakan memiliki keunggulan dalam sektor Bangunan karena daerah tersebut mempunyai nilai LQ lebih besar dari 1.

Sedangkan daerah yang tidak memiliki keunggulan dalam sektor bangunan/konstrusi dikarenakan daerah tersebut mempunyai nilai LQ kurang dari 1 adalah Kabupaten Pasuruan (0.58), Kabupaten Mojokerto (0.47), Kabupaten Sidoarjo (0.43), Kabupaten Malang (0.35), Kabupaten Blitar (0.41), Kota Batu (0.31) dan Kota Malang (0.52). Hal ini berarti pula bahwa sektor bangunan/konstruksi bukan merupakan suatu sektor unggulan daerah di Koridor Utara Selatan Propinsi Jawa Timur yang dapat terus dikembangkan untuk mendukung pertumbuhan ekonomi koridor tersebut.

\section{Gambar 6. Peta LQ (Location Quontient) Sektor Perdagangan, Hotel dan Restoran}




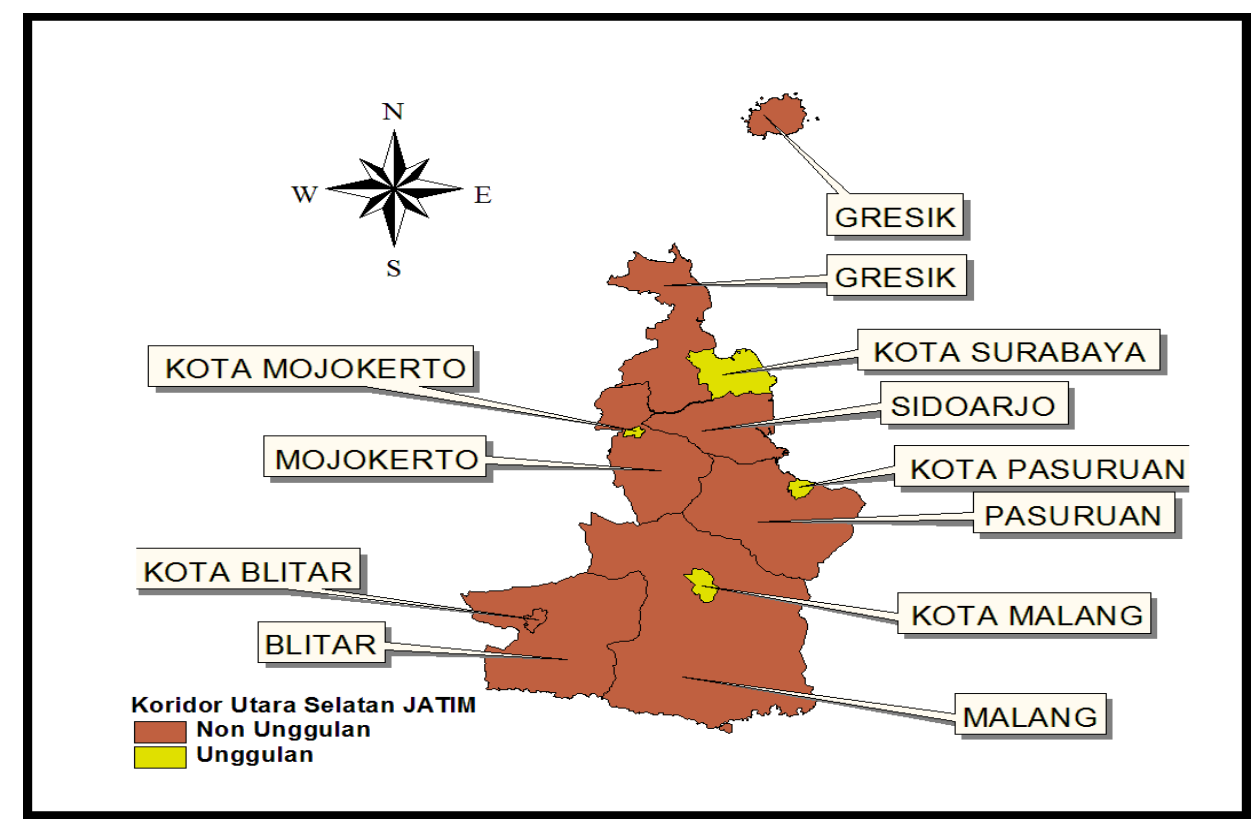

Sumber : Location Quontiet data diolah

Gambar 6 menunjukkan bahwa dengan analisa LQ (Location Quontient) sektor perdagangan, hotel dan restoran Kabupaten/Kota Koridor Utara Selatan Propinsi Jawa Timur, menunjukkan bahwa daerah yang memiliki keunggulan dalam sektor ini adalah Kota Batu (1.54), Kota Malang (1.21), Kota Kota Mojokerto (1.20). Daerah tersebut dapat dinyatakan memiliki keunggulan dalam sektor perdagangan, hotel dan restoran karena daerah tersebut mempunyai nilai LQ lebih besar dari 1.

Sedangkan daerah yang tidak memiliki keunggulan dalam sektor perdagangan, hotel dan restoran dikarenakan daerah tersebut mempunyai nilai LQ kurang dari 1 adalah Kabupaten Gresik (0.75), Kabupaten Pasuruan (0.72), Kabupaten Mojokerto (0.73), Kabupaten Sidoarjo (0.80), Kabupaten Malang (0.77), Kabupaten Blitar (0.80) dan Kota Blitar (0.79).

Hal ini berarti pula bahwa sektor perdagangan, hotel dan restoran bukan merupakan suatu sektor unggulan daerah di Koridor Utara Selatan Propinsi Jawa Timur yang dapat terus dikembangkan untuk mendukung pertumbuhan ekonomi koridor tersebut. 


\section{Gambar 7. Peta LQ (Location Quontient) Sektor Pengangkutan dan Komunikasi}

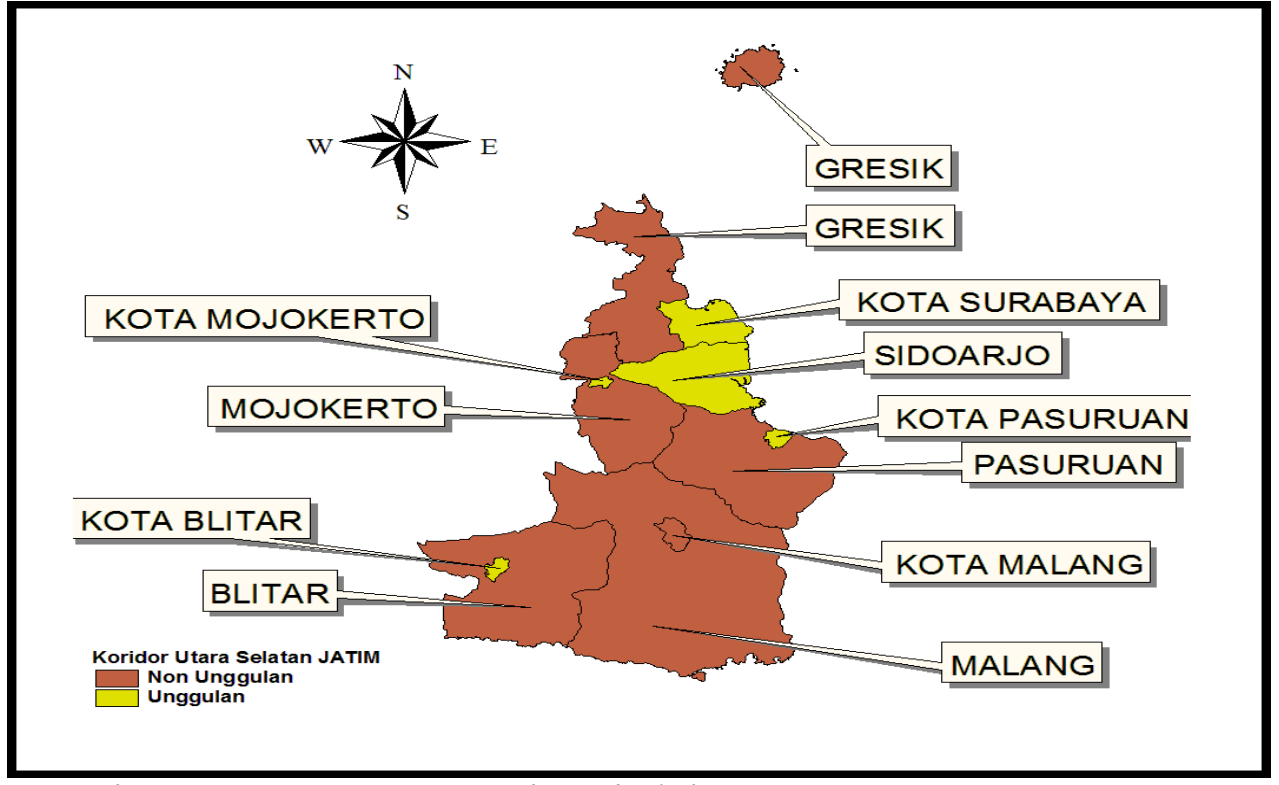

Sumber : Location Quontiet data diolah

Gambar 7 menunjukkan bahwa dengan analisa LQ (Location Quontient) sektor pengangkutan dan komunikasi Kabupaten/Kota Koridor Utara Selatan Propinsi Jawa Timur, menunjukkan bahwa daerah yang memiliki keunggulan dalam sektor ini Kota Mojokerto (2.26), Kota Blitar (1.81), Kota Pasuruan (1.59). Daerah tersebut dapat dinyatakan memiliki keunggulan dalam sektor pengangkutan dan komunikasi karena daerah tersebut mempunyai nilai LQ lebih besar dari 1.

Sedangkan daerah yang tidak memiliki keunggulan dalam sektor Pengangkutan dan Komunikasi dikarenakan daerah tersebut mempunyai nilai LQ kurang dari 1 adalah Kabupaten Gresik (0.35), Kabupaten Pasuruan (0.34), Kabupateen Mojokerto (0.50), Kabupaten Malang (0.50), Kabupaten Blitar (0.24), Kota Batu (0.40) dan Kota Malang (0.55).

Hal ini berarti pula bahwa sektor pengangkutan dan komunikasi bukan merupakan suatu sektor unggulan daerah di Koridor Utara Selatan Propinsi Jawa Timur yang dapat terus dikembangkan untuk mendukung pertumbuhan ekonomi koridor tersebut.

Gambar 8. Peta LQ (Location Quontient) Sektor Keuangan, Persewaan dan 
Jasa Perusahaan

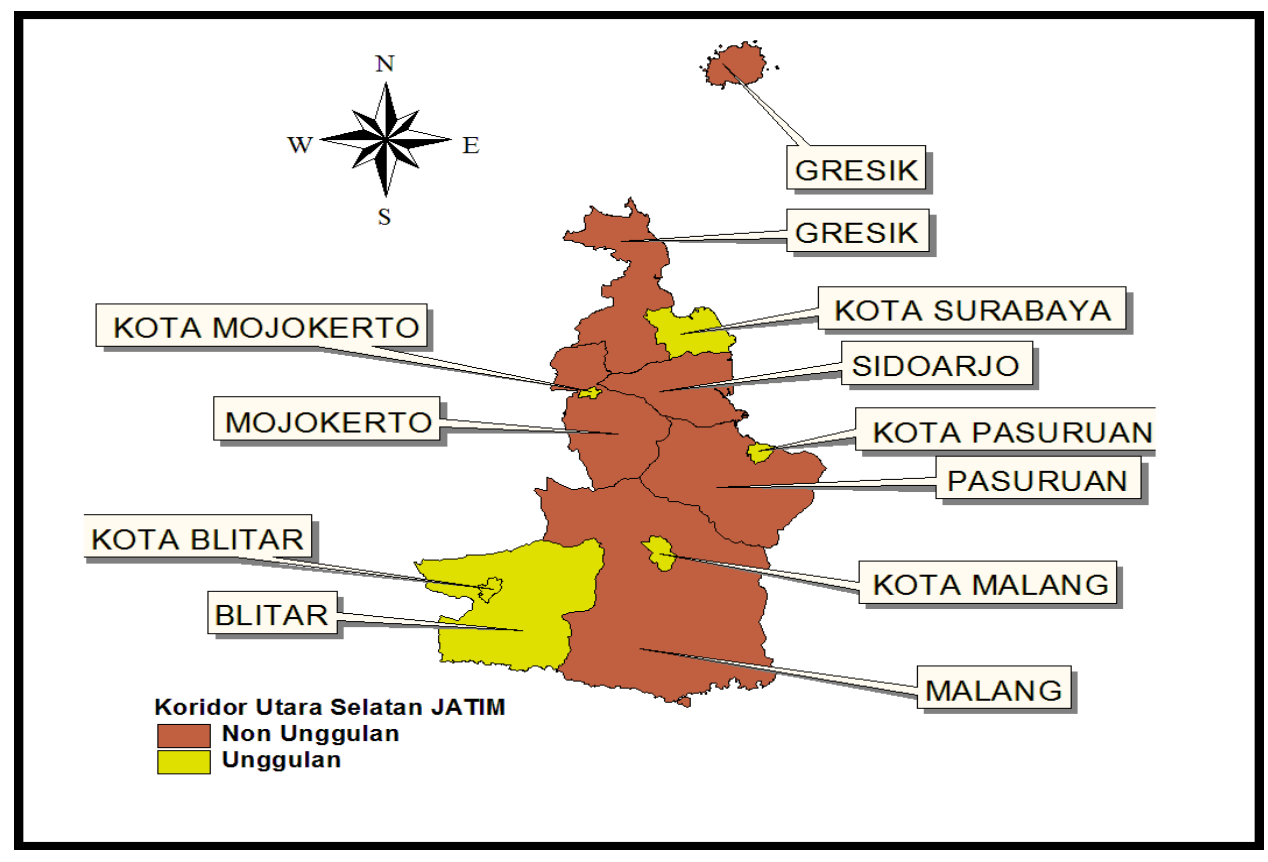

Sumber : Location Quontiet data diolah

Gambar 8 menunjukkan bahwa dengan analisa LQ (Location Quontien) sektor keuangan, persewaan, dan jasa perusahaan Kabupaten/Kota Koridor Utara Selatan Propinsi Jawa Timur, menunjukkan bahwa daerah yang memiliki keunggulan dalam sektor ini adalah Kota Blitar (2.58), Kota Malang (1.68) dan Kota Pasuruan (1.60). Daerah tersebut dapat dinyatakan memiliki keunggulan dalam sektor keuangan, persewaan, dan jasa perusahaan karena daerah tersebut mempunyai nilai LQ lebih besar dari 1.

Sedangkan daerah yang tidak memiliki keunggulan dalam sektor keuangan, persewaan, dan jasa perusahaan adalah Kabupaten Gresik (0.70), Kabupaten Pasuruan (0.75), Kabupaten Mojokerto (0.69), Kabupaten Sidoarjo (0.24), Kabupaten Malang (0.74) dan Kota Batu (0.84). Hal ini dikarenakan daerah tersebut mempunyai nilai LQ kurang dari 1.

Gambar 9. Peta LQ (Location Quontient) Sektor Jasa-Jasa 


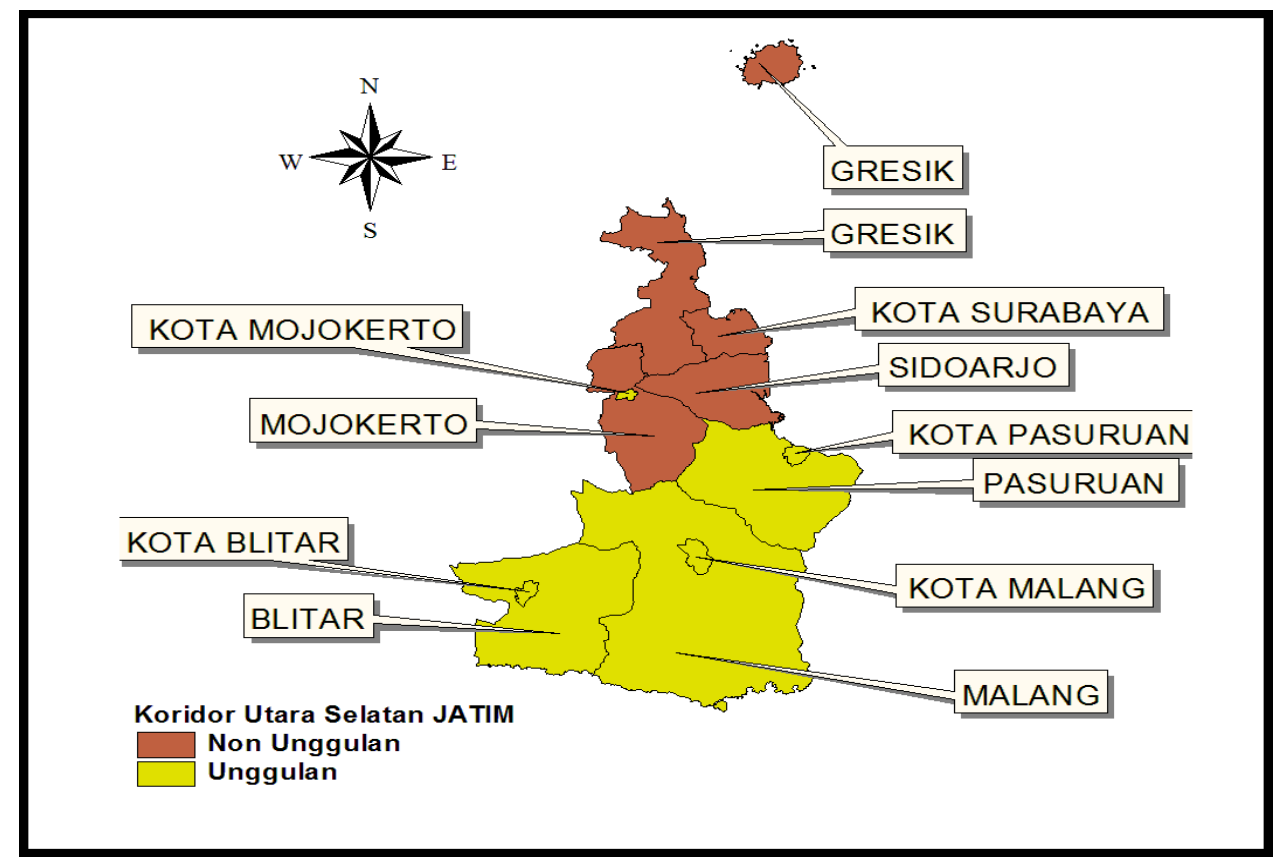

Sumber : Location Quontiet data diolah

Gambar 9 menunjukkan bahwa dengan analisa LQ (Location Quontient) sektor jasa-jasa Kabupaten/Kota Koridor Utara Selatan Propinsi Jawa Timur, menunjukkan bahwa daerah yang memiliki keunggulan dalam sektor ini adalah Kota Blitar (2.58), Kabupaten Malang (1.81), Kota Batu (1.71). Daerah tersebut dapat dinyatakan memiliki keunggulan dalam sektor jasa-jasa karena daerah tersebut mempunyai nilai LQ lebih besar dari 1 .

Sedangkan daerah yang tidak memiliki keunggulan dalam sektor jasa-jasa dikarenakan daerah tersebut mempunyai nilai LQ kurang dari 1 adalah Kabupaten Gresik (0.26),
Kabupaten Mojokerto (0.90), Kabupaten Sidoarjo (0.58) dan Kota Surabaya (0.95). Hal ini berarti pula bahwa sektor jasa-jasa merupakan suatu sektor unggulan daerah di Koridor Utara Selatan Propinsi Jawa Timur yang dapat terus dikembangkan untuk mendukung pertumbuhan ekonomi koridor tersebut.

Tahapan analisis berikutnya yaitu analisis kontribusi sektor ekonomi, Analisis kontribusi adalah analisis yang digunakan untuk mengetahui kontribusi suatu daerah terhadap daerah yang lebih luas misalnya jumlah Produk Domestik Regional Bruto (PDRB) sektor atau sub sektor tertentu terhadap total 
Produk Domestik Regional Bruto (PDRB). Dengan mengetahui kontribusi sektor dan sub sektor tersebut maka kita dapat mengetahui sektor dan sub sektor yang banyak berperan dalam daerah dan mempermudah pemerintah dalam pengembangan potensi daerah.

Sektor ekonomi yang memberikan konstribusi rata-rata terhadap Kabupaten Gresik tiga terbesar diberikan oleh sektor industri pengolahan sebesar $45.29 \%$, meliputi kontribusi dari sub sektor makanan, minuman dan tembakau $4.13 \%$, tekstil, barang dari kulit, dan alas kaki $6.37 \%$, barang dari kayu dan hasil hutan lainnya 7.36\%, kertas dan barang cetakan 3.97\%, pupuk, kimia dan barang dari karet $16.34 \%$, semen dan barang galian bukan logam $2.66 \%$, logam dasar besi dan baja $1.84 \%$, alat angkutan, mesin dan peralatannya $2.26 \%$, barang lainnya $0.07 \%$. Sektor perdagangan, hotel dan restoran $25.36 \%$ meliputi kontribusi dari sub sektor perdagangan $22.94 \%$, hotel $0.06 \%$, restoran $2.36 \%$. Sektor pertanian 9.31\% meliputi kontribusi dari sub sektor tanaman bahan makanan
$3.52 \%$, tanaman perkebunan $0.14 \%$, peternakan $1.62 \%$, perikanan $4.03 \%$.

Sektor ekonomi yang memberikan konstribusi rata-rata terkecil terhadap Kabupaten Gresik adalah sektor jasa-jasa sebesar $1.93 \%$, meliputi kontribusi dari sub sektor pemerintahan umum $1.13 \%$, dan swasta $0.80 \%$ yang meliputi jasa sosial kemasyarakatan 0.26, jasa hiburan dan kebudayaan $0.07 \%$, jasa perorangan dan rumah tangga $0.47 \%$. Berdasarkan hasil analisis di atas diketahui bahwa sektor yang memberikan konstribusi besar terhadap perekonomian Kabupaten Gresik, maka akan mempengaruhi perekonomian Kabupaten Gresik dan semakin besar konstribusi sektoral terhadap perekonomian maka sektor tersebut memiliki potensi tinggi terhadap perkembangan ekonomi. Dari sembilan sektor yang ada, tiga sektor yang memiliki kontribusi terbesar dibandingkan sektor lainnya yaitu sektor industri pengolahan, sektor perdagangan, hotel dan restoran, sektor pertanian.

Sektor ekonomi yang memberikan konstribusi rata-rata terhadap Kabupaten Pasuruan tiga terbesar diberikan oleh sektor 
industri pengolahan $31.53 \%$ meliputi kontribusi dari sub sektor makanan, minuman dan tembakau $16.47 \%$, tekstil, barang dari kulit, dan alas kaki $1.04 \%$, barang dari kayu dan hasil hutan lainnya $1.16 \%$, kertas dan barang cetakan $3.98 \%$, pupuk, kimia dan barang dari karet $3.07 \%$, semen dan barang galian bukan logam $0.65 \%$, logam dasar besi dan baja $0.72 \%$, alat angkutan, mesin dan peralatannya $3.45 \%$, barang lainnya $1.01 \%$. Sektor perdagangan, hotel dan restoran $24.07 \%$ meliputi kontribusi dari sub sektor perdagangan $16.15 \%$, hotel $5.26 \%$, restoran $2.66 \%$. Sektor pertanian $22.81 \%$ meliputi kontribusi dari sub sektor tanaman bahan makanan $14.61 \%$, tanaman perkebunan $3.03 \%$, peternakan $3.77 \%$, kehutanan $0.04 \%$, perikanan $1.36 \%$.

Sektor ekonomi yang memberikan konstribusi rata-rata terkecil terhadap Kabupaten Pasuruan adalah sektor pertambangan dan penggalian $1.35 \%$ meliputi kontribusi dari sub sektor pertambangan non-migas $0.01 \%$, dan penggalian $1.34 \%$.

Berdasarkan hasil analisis di atas diketahui bahwa sektor yang memberikan konstribusi besar terhadap perekonomian Kabupaten Pasuruan, maka akan mempengaruhi perekonomian Kabupaten Pasuruan dan semakin besar konstribusi sektoral terhadap perekonomian maka sektor tersebut memiliki potensi tinggi terhadap perkembangan ekonomi. Dari sembilan sektor yang ada, tiga sektor yang memiliki kontribusi terbesar dibandingkan sektor lainnya yaitu sektor industri pengolahan, sektor perdagangan, hotel dan restoran, sektor pertanian.

Sektor ekonomi yang memberikan konstribusi rata-rata terhadap Kabupaten Mojokerto tiga terbesar diberikan oleh sektor industri pengolahan $35.23 \%$ meliputi kontribusi dari sub sektor makanan, minuman dan tembakau $19.31 \%$, tekstil, barang dari kulit, dan alas kaki $0.59 \%$, barang dari kayu dan hasil hutan lainnya $0.55 \%$, kertas dan barang cetakan $13.75 \%$, pupuk, kimia dan barang dari karet $0.32 \%$, semen dan barang galian bukan logam $0.66 \%$, logam dasar besi dan baja $0.02 \%$, alat angkutan, mesin dan peralatannya $0.01 \%$, barang lainnya $0.02 \%$. Sektor perdagangan, hotel 
dan restoran $24.44 \%$ meliputi kontribusi dari sub sektor perdagangan $20.96 \%$, hotel $0.38 \%$, restoran $3.10 \%$. Sektor pertanian $21.40 \%$ meliputi kontribusi dari sub sektor tanaman bahan makanan $10.64 \%$, tanaman perkebunan $3.13 \%$, peternakan $7.53 \%$, kehutanan $0.05 \%$, perikanan $0.04 \%$.

Sektor ekonomi yang memberikan konstribusi rata-rata terkecil terhadap Kabupaten Mojokerto adalah sektor listrik dan air bersih $1.04 \%$ meliputi kontribusi dari sub sektor listrik $1.02 \%$ dan air bersih $0.02 \%$.

Berdasarkan hasil analisis di atas diketahui bahwa sektor yang memberikan konstribusi besar terhadap perekonomian Kabupaten Mojokerto, maka akan mempengaruhi perekonomian Kabupaten Mojokerto dan semakin besar konstribusi sektoral terhadap perekonomian maka sektor tersebut memiliki potensi tinggi terhadap perkembangan ekonomi. Dari sembilan sektor yang ada, tiga sektor yang memiliki kontribusi terbesar dibandingkan sektor lainnya yaitu sektor industri pengolahan, sektor perdagangan, hotel dan restoran, sektor pertanian.

Sektor ekonomi yang memberikan konstribusi rata-rata terhadap Kabupaten Sidoarjo tiga terbesar diberikan oleh sektor industri pengolahan $50.18 \%$ meliputi kontribusi dari sub sektor makanan, minuman dan tembakau 9.88\%, tekstil, barang dari kulit, dan alas kaki $2.10 \%$, barang dari kayu dan hasil hutan lainnya $0.93 \%$, kertas dan barang cetakan 18.15\%, pupuk, kimia dan barang dari karet $7.94 \%$, semen dan barang galian bukan logam $1.49 \%$, logam dasar besi dan baja $4.56 \%$, alat angkutan, mesin dan peralatannya $2.23 \%$, barang lainnya $2.91 \%$. Sektor perdagangan, hotel dan restoran $26.99 \%$ meliputi kontribusi dari sub sektor perdagangan 25.91, hotel $0.09 \%$, restoran $0.99 \%$. Sektor pengangkutan dan komunikasi $10.04 \%$ meliputi kontribusi dari sub sektor angkutan 9.33\% meliputi angkutan rel $0.01 \%$, angkutan jalan raya $0.78 \%$, angkutan udara $7.93 \%$, jasa penunjang angkutan $0.61 \%$, dan sub sektor komunikasi $0.71 \%$.

Sektor ekonomi yang memberikan konstribusi rata-rata 
terkecil terhadap Kabupaten Sidoarjo adalah sektor pertambangan dan penggalian $0.20 \%$ dengan kontribusi dari sub sektor pertambangan migas $0.15 \%$, dan penggalian $0.04 \%$.

Berdasarkan hasil analisis di atas diketahui bahwa sektor yang memberikan konstribusi besar terhadap perekonomian Kabupaten Sidoarjo, maka akan mempengaruhi perekonomian Kabupaten Sidoarjo dan semakin besar konstribusi sektoral terhadap perekonomian maka sektor tersebut memiliki potensi tinggi terhadap perkembangan ekonomi. Dari sembilan sektor yang ada, tiga sektor yang memiliki kontribusi terbesar dibandingkan sektor lainnya yaitu sektor industri pengolahan, sektor perdagangan, hotel dan restoran, Pengangkutan dan Komunikasi.

Sektor ekonomi yang memberikan konstribusi rata-rata terhadap Kabupaten Malang tiga terbesar diberikan oleh sektor pertanian $28.86 \%$ meliputi kontribusi dari sub sektor Tanaman Bahan Makanan $16.73 \%$, tanaman perkebunan $7.26 \%$, peternakan $4.33 \%$, kehutanan $0.16 \%$, perikanan $0.38 \%$. Sektor perdagangan, hotel dan restoran $26.02 \%$ meliputi kontribusi dari sub sektor perdagangan $24.30 \%$, hotel $0.42 \%$, restoran $1.30 \%$. Sektor industri pengolahan $17.86 \%$ meliputi kontribusi dari sub sektor makanan, minuman dan tembakau $7.41 \%$, tekstil, barang dari kulit, dan alas kaki $2.01 \%$, barang dari kayu dan hasil hutan lainnya $0.23 \%$, kertas dan barang cetakan $1.51 \%$, pupuk, kimia dan barang dari karet $4.24 \%$, semen dan barang galian bukan logam $1.32 \%$, alat angkutan, mesin dan peralatannya $0.09 \%$, barang lainnya $1.15 \%$. Sektor ekonomi yang memberikan konstribusi rata-rata terkecil terhadap Kabupaten Malang adalah Sektor bangunan/konstruksi $1.31 \%$.

Berdasarkan hasil analisis di atas diketahui bahwa sektor yang memberikan konstribusi besar terhadap perekonomian Kabupaten Malang, maka akan mempengaruhi perekonomian Kabupaten Malang dan semakin besar konstribusi sektoral terhadap perekonomian maka sektor tersebut memiliki potensi tinggi terhadap perkembangan ekonomi. Dari sembilan sektor yang ada, tiga sektor 
yang memiliki kontribusi terbesar dibandingkan sektor lainnya yaitu sektor pertanian, sektor perdagangan, hotel dan restoran, sektor industri pengolahan.

$$
\text { Sektor ekonomi yang }
$$
memberikan konstribusi rata-rata terhadap Kabupaten Blitar tiga terbesar diberikan oleh sektor pertanian $47.68 \%$ meliputi kontribusi dari sub sektor tanaman bahan makanan 20.86\%, tanaman perkebunan $5.72 \%$, peternakan 20.35, kehutanan $0.18 \%$, perikanan $0.57 \%$. Sektor perdagangan, hotel dan restoran $26.84 \%$ meliputi kontribusi dari sub sektor perdagangan $25.59 \%$, dan restoran $1.15 \%$. Sektor jasa-Jasa $9.72 \%$ meliputi kontribusi dari sub sektor pemerintahan umum $7.08 \%$, dan swasta $2.65 \%$ yang meliputi jasa sosial kemasyarakatan $0.62 \%$, jasa hiburan dan kebudayaan $0.04 \%$, jasa perorangan dan rumah tangga $1.98 \%$.

$$
\text { Sektor ekonomi yang }
$$
memberikan konstribusi rata-rata terkecil terhadap Kabupaten Blitar adalah sektor listrik dan air bersih $0.80 \%$ meliputi kontribusi dari sub sektor listrik $0.79 \%$, dan air bersih $0.01 \%$.
Berdasarkan hasil analisis di atas diketahui bahwa sektor yang memberikan konstribusi besar terhadap perekonomian Kabupaten Blitar, maka akan mempengaruhi perekonomian Kabupaten Blitar dan semakin besar konstribusi sektoral terhadap perekonomian maka sektor tersebut memiliki potensi tinggi terhadap perkembangan ekonomi. Dari sembilan sektor yang ada, tiga sektor yang memiliki kontribusi terbesar dibandingkan sektor lainnya yaitu sektor pertanian, sektor perdagangan, hotel dan restoran, sektor jasa-jasa.

Sektor ekonomi yang memberikan konstribusi rata-rata terhadap Kota Surabaya tiga terbesar diberikan oleh sektor perdagangan, hotel dan restoran $39.10 \%$ meliputi kontribusi dari sub sektor perdagangan $24.56 \%$, hotel $1.29 \%$, restoran $13.24 \%$. Sektor industri pengolahan $28.95 \%$ meliputi kontribusi dari sub sektor makanan, minuman dan tembakau $15.16 \%$, tekstil, barang dari kulit, dan alas kaki $0.29 \%$, barang dari kayu dan hasil hutan lainnya $0.15 \%$, kertas dan barang cetakan $3.53 \%$, pupuk, kimia dan barang dari karet $1.11 \%$, semen 
dan barang galian bukan logam $0.67 \%$, logam dasar besi dan baja $5.66 \%$, alat angkutan, mesin dan peralatannya $0.46 \%$, barang lainnya $1.93 \%$. Sektor pengangkutan dan komunikasi $\quad 10.32 \% \quad$ meliputi kontribusi dari sub sektor angkutan $6.12 \%$ yang meliputi angkutan rel $0.08 \%$, angkutan jalan raya $1.27 \%$, angkutan laut 0,69\%, angkutan penyebrangan $0,03 \%$, jasa penunjang angkutan $4.06 \%$, dan sub sektor komunikasi $4.20 \%$.

Sektor ekonomi yang memberikan konstribusi rata-rata terkecil terhadap Kota Surabaya adalah sektor pertambangan dan penggalian $\quad 0.01 \%$ meliputi kontribusi dari sub sektor penggalian $0.01 \%$.

Berdasarkan hasil analisis di atas diketahui bahwa sektor yang memberikan konstribusi besar terhadap perekonomian Kota Surabaya, maka akan mempengaruhi perekonomian Kota Surabaya dan semakin besar konstribusi sektoral terhadap perekonomian maka sektor tersebut memiliki potensi tinggi terhadap perkembangan ekonomi. Dari sembilan sektor yang ada, tiga sektor yang memiliki kontribusi terbesar dibandingkan sektor lainnya yaitu sektor perdagangan, hotel dan restoran, sektor industri pengolahan, sektor pengangkutan dan komunikasi.

Sektor ekonomi yang memberikan konstribusi rata-rata terhadap Kota Batu tiga terbesar diberikan oleh sektor perdagangan, hotel dan restoran $51.72 \%$ meliputi kontribusi dari sub sektor perdagangan $35.72 \%$, hotel 17.43 , restoran $2.38 \%$. Sektor pertanian $18.08 \%$ meliputi kontribusi dari sub sektor tanaman bahan makanan $15.46 \%$, tanaman perkebunan $0.15 \%$, peternakan $2.41 \%$, kehutanan $0.02 \%$, perikanan $0.03 \%$. Sektor jasa-jasa $12.62 \%$ meliputi kontribusi dari sub sektor pemerintahan umum $5.01 \%$, dan swasta $7.60 \%$ meliputi jasa sosial kemasyarakatan $1.02 \%$, jasa hiburan dan kebudayaan $1.66 \%$, jasa perorangan dan rumah tangga $4.92 \%$.

Sektor ekonomi yang memberikan konstribusi rata-rata terkecil terhadap Kota Batu adalah sektor pertambangan dan penggalian $0.24 \%$ meliputi kontribusi dari sub sektor penggalian $0.24 \%$.

Berdasarkan hasil analisis di atas diketahui bahwa sektor yang 
memberikan konstribusi besar terhadap perekonomian Kota Batu, maka akan mempengaruhi perekonomian Kota Batu dan semakin besar konstribusi sektoral terhadap perekonomian maka sektor tersebut memiliki potensi tinggi terhadap perkembangan ekonomi. Dari sembilan sektor yang ada, tiga sektor yang memiliki kontribusi terbesar dibandingkan sektor lainnya yaitu sektor perdagangan, hotel dan restoran, sektor pertanian, sektor jasa-jasa.

Sektor ekonomi yang memberikan konstribusi rata-rata terhadap Kota Pasuruan tiga terbesar diberikan oleh sektor perdagangan, hotel dan restoran $40.07 \%$ meliputi kontribusi dari sub sektor perdagangan $34.89 \%$, hotel $0.70 \%$, restoran $4.49 \%$. Sektor industri pengolahan $14.29 \%$ meliputi kontribusi dari sub sektor makanan, minuman dan tembakau $1.21 \%$, tekstil, barang dari kulit, dan alas kaki $0.27 \%$, barang dari kayu dan hasil hutan lainnya $5.50 \%$, kertas dan barang cetakan $0.20 \%$, pupuk, kimia dan barang dari karet $0.17 \%$, semen dan barang galian bukan logam $0.40 \%$, logam dasar besi dan baja
$0.09 \%$, alat angkutan, mesin dan peralatannya $6.36 \%$, barang lainnya $0.10 \%$. Sektor pengangkutan dan komunikasi $12.53 \%$ meliputi kontribusi sub sektor angkutan $6.68 \%$ meliputi angkutan rel $0.10 \%$, angkutan jalan raya 5.13\%, angkutan laut $0.20 \%$, jasa penunjang angkutan $1.26 \%$, dan sub sektor komunikasi sebesar $5.85 \%$.

Sektor ekonomi yang memberikan konstribusi rata-rata terkecil terhadap Kota Pasuruan adalah sektor pertambangan dan penggalian $\quad 0.19 \%$ meliputi kontribusi dari sub sektor penggalian $0.19 \%$.

Berdasarkan hasil analisis di atas diketahui bahwa sektor yang memberikan konstribusi besar terhadap perekonomian Kota Pasuruan, maka akan mempengaruhi perekonomian Kota Pasuruan dan semakin besar konstribusi sektoral terhadap perekonomian maka sektor tersebut memiliki potensi tinggi terhadap perkembangan ekonomi. Dari sembilan sektor yang ada, tiga sektor yang memiliki kontribusi terbesar dibandingkan sektor lainnya yaitu sektor perdagangan, hotel dan restoran, sektor industri pengolahan 
sektor pengangkutan dan

tanaman perkebunan $0.02 \%$, komunikasi. peternakan $0.37 \%$, perikanan $0.01 \%$. Sektor ekonomi yang Sektor yang tidak memberikan memberikan konstribusi rata-rata terhadap Kota Mojokerto tiga terbesar diberikan oleh sektor perdagangan, hotel dan restoran 40.29\% meliputi kontribusi dari sub sektor perdagangan $28.39 \%$, hotel $0.57 \%$, restoran $11.33 \%$. Sektor pengangkutan dan komunikasi $17.83 \%$ meliputi kontribusi dari sub sektor angkutan $8.04 \%$ yang meliputi angkutan rel $0.16 \%$, angkutan jalan raya $6.72 \%$, jasa penunjang angkutan $1.16 \%$ dan sub sektor komunikasi 9.78\%. Sektor industri pengolahan $13.64 \%$ meliputi kontribusi dari sub sektor makanan, minuman dan tembakau $1.44 \%$, tekstil, barang dari kulit, dan alas kaki 5.11\%, barang dari kayu dan hasil hutan lainnya $0.29 \%$, kertas dan barang cetakan $0.35 \%$, pupuk, kimia dan barang dari karet $0.28 \%$, logam dasar besi dan baja $0.20 \%$, barang lainnya $5.98 \%$.

Sektor ekonomi yang memberikan konstribusi rata-rata terkecil terhadap Kota Mojokerto adalah sektor pertanian $0.85 \%$ meliputi kontribusi dari sub sektor tanaman bahan makanan $0.45 \%$, konstribusi terhadap Kota Mojokerto adalah sektor pertambangan dan penggalian $0.00 \%$.

Berdasarkan hasil analisis di atas diketahui bahwa sektor yang memberikan konstribusi besar terhadap perekonomian Kota Pasuruan, maka akan mempengaruhi perekonomian Kota Pasuruan dan semakin besar konstribusi sektoral terhadap perekonomian maka sektor tersebut memiliki potensi tinggi terhadap perkembangan ekonomi. Dari sembilan sektor yang ada tiga sektor yang memiliki konstribusi terbesar dibandingkan sektor lainnya yaitu sektor perdagangan, hotel dan restoran, sektor pengangkutan dan komunikasi, sektor industri pengolahan.

Sektor ekonomi yang memberikan konstribusi rata-rata terhadap Kota Malang tiga terbesar diberikan oleh sektor perdagangan, hotel dan restoran $40.81 \%$ meliputi kontribusi dari sub sektor perdagangan $36.89 \%$, hotel $1.62 \%$, restoran $2.29 \%$. Sektor industri pengolahan $31.29 \%$ meliputi 
kontribusi dari sub sektor makanan, minuman dan tembakau 29.27\%, tekstil, barang dari kulit, dan alas kaki $0.49 \%$, barang dari kayu dan hasil hutan lainnya $0.10 \%$, kertas dan barang cetakan $0.69 \%$, pupuk, kimia dan barang dari karet $0.11 \%$, alat angkutan, mesin dan peralatannya $0.03 \%$, barang lainnya $0.45 \%$. Sektor jasa-jasa $12.13 \%$ meliputi kontribusi dari sub sektor pemerintahan umum $1.95 \%$ dan swasta $10.17 \%$ meliputi jasa sosial kemasyarakatan $2.64 \%$, jasa hiburan dan kebudayaan 1.48\%, jasa perorangan dan rumah tangga $6.05 \%$.

Sektor ekonomi yang memberikan konstribusi rata-rata terkecil terhadap Kota Malang adalah sektor pertambangan dan penggalian $\quad 0.08 \%$ meliputi kontribusi dari sub sektor penggalian $0.08 \%$.

Berdasarkan hasil analisis di atas diketahui bahwa sektor yang memberikan konstribusi besar terhadap perekonomian Kota Malang, maka akan mempengaruhi perekonomian Kota Malang dan semakin besar konstribusi sektoral terhadap perekonomian maka sektor tersebut memiliki potensi tinggi terhadap perkembangan ekonomi. Dari sembilan sektor yang ada, tiga sektor yang memiliki kontribusi terbesar dibandingkan sektor lainnya yaitu sektor perdagangan, hotel dan restoran, sektor industri pengolahan, sektor jasa-jasa.

Sektor ekonomi yang memberikan konstribusi rata-rata terhadap Kota Blitar tiga terbesar diberikan oleh sektor perdagangan, hotel dan restoran $40.81 \%$ meliputi kontribusi dari sub sektor perdagangan $20.23 \%$, hotel $1.36 \%$, restoran $5.09 \%$. Sektor jasa-jasa $12.13 \%$ meliputi kontribusi dari sub sektor pemerintahan umum $10.21 \%$ dan swasta $8.83 \%$ meliputi jasa sosial kemasyarakatan $1.25 \%$, jasa hiburan dan kebudayaan $0.62 \%$, jasa perorangan dan rumah tangga $6.95 \%$. Sektor pengangkutan dan komunikasi $\quad 4.37 \%$ meliputi kontribusi dari sub sektor angkutan $7.52 \%$ yang meliputi angkutan rel $0.36 \%$, angkutan jalan raya $3.34 \%$, jasa penunjang angkutan $3.82 \%$ dan sub sektor komunikasi $6.73 \%$.

Sektor ekonomi yang memberikan konstribusi rata-rata terkecil terhadap Kota Blitar adalah Sektor pertambangan dan penggalian 
$0.08 \%$ meliputi kontribusi dari sub sektor penggalian $0.08 \%$.

Berdasarkan hasil analisis di atas diketahui bahwa sektor yang memberikan konstribusi besar terhadap perekonomian Kota Blitar, maka akan mempengaruhi perekonomian Kota Blitar dan semakin besar konstribusi sektoral terhadap perekonomian maka sektor tersebut memiliki potensi tinggi terhadap perkembangan ekonomi. Dari sembilan sektor yang ada, tiga sektor yang memiliki kontribusi terbesar dibandingkan sektor lainnya yaitu sektor perdagangan, hotel dan restoran, sektor jasa-jasa, sektor pengangkutan dan komunikasi.

Sektor ekonomi yang memberikan konstribusi rata-rata terhadap Propinsi Jawa Timur tiga terbesar diberikan oleh sektor perdagangan, hotel dan restoran $29.93 \%$ meliputi kontribusi dari sub sektor perdagangan $24.32 \%$, hotel $0.85 \%$, restoran $4.76 \%$. Sektor industri pengolahan $26.67 \%$ meliputi kontribusi dari sub sektor makanan, minuman dan tembakau $14.32 \%$, tekstil, barang dari kulit, dan alas kaki $0.95 \%$, barang dari kayu dan hasil hutan lainnya $0.74 \%$, kertas dan barang cetakan $3.82 \%$, pupuk, kimia dan barang dari karet $2.11 \%$, semen danb galian bukan logam $0.91 \%$, logam dasar besi dan baja $1.63 \%$, alat angkutan, mesin dan peralatannya $0.70 \%$, barang lainnya $0.89 \%$. Sektor pertanian $16.54 \%$ meliputi kontribusi dari sub sektor tanaman bahan makanan $9.21 \%$, tanaman perkebunan $2.70 \%$, peternakan $2.69 \%$, kehutanan $0.18 \%$, perikanan $1.76 \%$.

Sektor ekonomi yang memberikan konstribusi rata-rata terkecil terhadap Propinsi Jawa Timur adalah Sektor listrik dan air bersih $1.59 \%$ meliputi kontribusi dari sub sektor listrik $1.21 \%$, gas kota $0.30 \%$, air bersih $0.09 \%$.

Berdasarkan hasil analisis di atas diketahui bahwa sektor yang memberikan konstribusi besar terhadap perekonomian Propinsi Jawa Timur, maka akan mempengaruhi perekonomian Propinsi Jawa Timur dan semakin besar konstribusi sektoral terhadap perekonomian maka sektor tersebut memiliki potensi tinggi terhadap perkembangan ekonomi. Dari sembilan sektor yang ada, tiga sektor yang memiliki kontribusi terbesar 
dibandingkan sektor lainnya yaitu sektor perdagangan, hotel dan restoran, sektor industri pengolahan, sektor pertanian.

Analisis berikutnya yaitu analisis tipologi klassen, analisis ini digunakan untuk mengetahui gambaran tentang pola dan struktur pertumbuhan ekonomi masingmasing daerah. Pada dasarnya tipologi klassen membagi daerah menjadi dua indikator utama, yaitu pertumbuhan ekonomi daerah dan pendapatan perkapita daerah.

Dengan menentukan rata-rata petumbuhan ekonomi sebagai sumbu vertikal dan rata-rata pendapatan perkapita sebagai sumbu horizontal. Jadi, analisis ini membandingkan antara rasio pendapatan perkapita dengan pertumbuhan ekonomi. Daerah yang diamati dapat dibagi menjadi empat klasifikasi, yaitu: pertama, daerah cepat maju dan cepat tumbuh ( high growth and high income) adalah daerah yang memiliki tingkat pertumbuhan ekonomi dan pendapatan perkapita yang lebih tinggi dibandingkan daerah referensi. Kedua, Daerah maju tapi tertekan (high income but low growth) adalah daerah yang memiliki pendaatan perkapita lebih tinggi tetapi tingkat pertumbuhan ekonominya lebih rendah dibandingkan daerah referensi.

Ketiga, daerah berkembang cepat (high growth but low income) adalah daerah yang memiliki tingkat pertumbuhan ekonomi tinggi tetapi tingkat pendapatan perkapita lebih rendah dibanding daerah referensi. Keempat, daerah relatif tertinggal (low growth and low income) adalah daerah yang memiliki tingkat pendapatkan perkapita dan tingkat pertumbuhan ekonomi yang lebih rendah dibandingkan dengan referensi.

Tabel 1. Hasil Pola dan Struktur Pertumbuhan Ekonomi Koridor Utara Selatan Propinsi Jawa Timur 


\begin{tabular}{llll}
\hline \multicolumn{1}{c}{ Kabupaten/Kota } & $\begin{array}{c}\text { PDRB Per } \\
\text { Kapita }\end{array}$ & $\begin{array}{c}\text { Pertumbuhan } \\
\text { PDRB }\end{array}$ & \multicolumn{1}{c}{ Tipologi Klassen } \\
\hline Kab. Gresik & Tinggi & Rendah & Maju Tertekan \\
Kab. Pasuruhan & Rendah & Tinggi & Berkembang Cepat \\
Kab. Mojokerto & Rendah & Rendah & Tertinggal \\
Kab. Sidoarjo & Tinggi & Rendah & Maju Tertekan \\
Kab. Malang & Rendah & Rendah & Tertinggal \\
Kab. Blitar & Rendah & Tinggi & Berkembang Cepat \\
Kota Surabaya & Tinggi & Tinggi & Cepat Maju dan Tumbuh \\
Kota Batu & Rendah & Tinggi & Berkembang Cepat \\
Kota Pasuruhan & Rendah & Tinggi & Berkembang Cepat \\
Kota Mojokerto & Tinggi & Tinggi & Cepat Maju dan Tumbuh \\
Kota Malang & Tinggi & Rendah & Maju Tertekan \\
Kota Blitar & Rendah & Tinggi & Berkembang Cepat \\
\hline
\end{tabular}

Sumber : data diolah

Berdasarkan analisis Tipologi Klassen, dapat dijelaskan bahwa pola perekonomian Kabupaten/Kota di Koridor Utara Selatan Propinsi Jawa Timur terbagi atas empat klasifikasi yaitu Maju Tertekan, Berkembang Cepat, Terbelakang serta cepat Maju dan Tumbuh. Kabupaten/kota yang termasuk klasifikasi daerah Maju
Tertekan adalah Kabupaten Gresik, Kabupaten Sidoarjo dan Kota Malang, hal ini dikarenakan Kabupaten Gresik, Kabupaten Sidoarjo dan Kota Malang memiliki produk domestik regional bruto ratarata perkapita yang tinggi namun memiliki pertumbuhan produk domestik regional bruto rendah.

Gambar 10. Hasil Pola dan Struktur Pertumbuhan Ekonomi Koridor Utara Selatan Propinsi Jawa Timur 


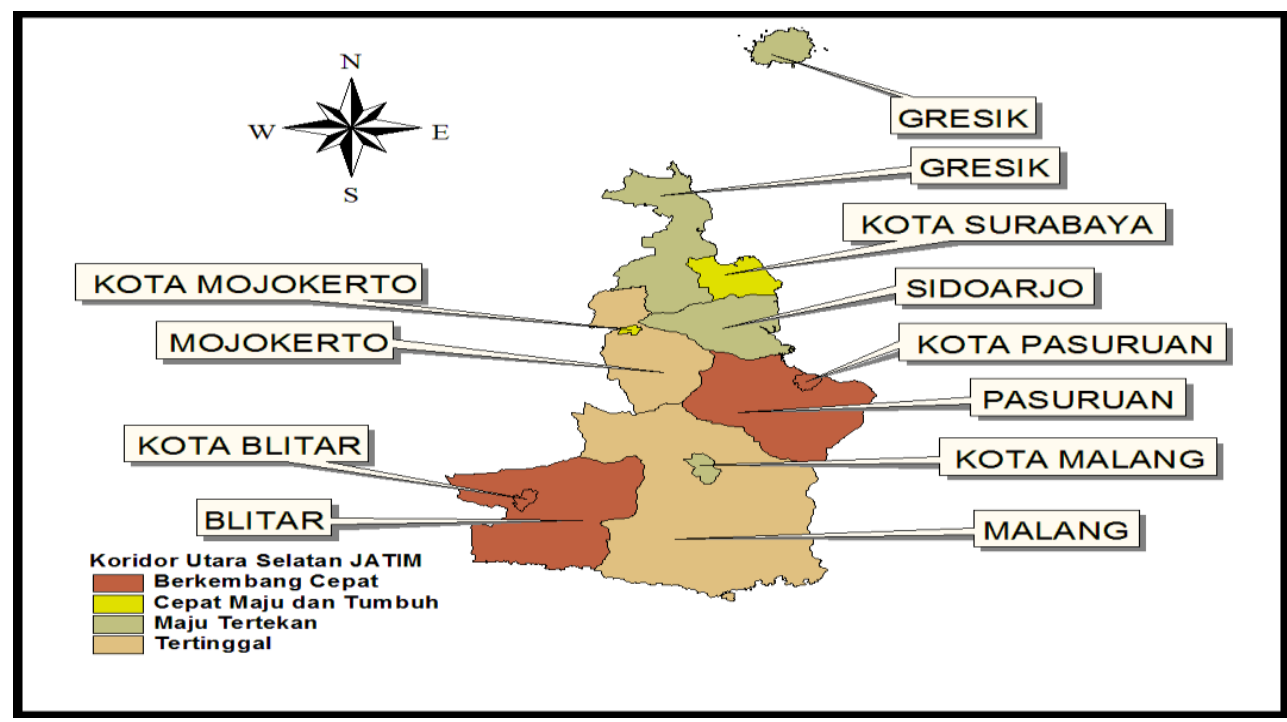

Sumber : Location Quontiet data diolah

Klasifikasi daerah yang dan memiliki pertumbuhan produk mempunyai pola pertumbuhan ekonomi Berkembang Cepat, adalah Kabupaten Pasuruan, Kabupaten Blitar, Kota Batu, Kota Pasuruan dan Kota Blitar, hal ini dikarenakan Kabupaten Pasuruan, Kabupaten Blitar, Kota Batu, Kota Pasuruan dan Kota Blitar memiliki produk domestik regional bruto rata-rata perkapita yang rendah namun memiliki pertumbuhan produk domestik regional bruto tinggi.

Klasifikasi daerah yang mempunyai pola pertumbuhan ekonomi Cepat maju dan Tumbuh adalah Kota Surabaya dan Kota Mojokerto, hal ini dikarenakan Kota Surabaya dan Kota Mojokerto memiliki produk domestik regional bruto rata-rata perkapita yang tinggi domestik regional bruto tinggi.

Klasifikasi daerah yang mempunyai pola pertumbuhan ekonomi Tertinggal adalah Kabupaten Mojokerto dan Kabupaten Malang, hal ini dikarenakan Kabupaten Mojokerto dan Kabupaten Malang memiliki produk domestik regional bruto ratarata perkapita yang rendah dan memiliki pertumbuhan produk domestik regional bruto rendah.

\section{PENUTUP}

Hasil analisis

Kabupaten/Kota Koridor Utara Selatan Propinsi Jawa Timur pada tahun 2005-2009 menunjukan bahwa nilai LQ sektoral terbesar diduduki oleh sektor pertanian di Kabupaten Blitar. sektor pertambangan dan 
penggalian di Kabupaten Malang, sektor industri pengolahan di Kabupaten Sidoarjo, sektor listrik, gas dan air bersih di Kabupaten Gresik, sektor bangunan/konstruksi di Kota Pasuruan, sektor perdagangan, hotel dan restoran di Kota Batu, sektor pengangkutan dan komunikasi di Kota Mojokerto, sektor keuangan, persewaan dan jasa perusahaan di Kota Blitar, sektor jasa-jasa di Kota Blitar.

Adapun hasil analisis Kontribusi sektoral ekonomi Kabupaten/Kota Koridor Utara Selatan Propinsi Jawa Timur sektor yang memberikan konstribusi terbesar adalah di Kabupaten Gresik konstribusi terbesar diberikan oleh sektor industri pengolahan, Kabupaten Pasuruan kontribusi terbesar diberikan oleh sektor industri pengolahan, Kabupaten Mojokerto kontribusi terbesar diberikan oleh sektor industri pengolahan, Kabupaten Sidoarjo kontribusi terbesar diberikan oleh sektor industri pengolahan sebesar, Kabupaten Malang kontribusi terbesar diberikan oleh sektor pertanian, Kabupaten Blitar kontribusi terbesar diberikan oleh sektor Pertanian, Kota Surabaya kontribusi terbesar diberikan oleh sektor perdagangan, hotel dan restoran, Kota Batu kontribusi terbesar diberikan oleh sektor perdagangan, hotel dan restoran, Kota Pasuruan kontribusi terbesar diberikan oleh sektor perdagangan, hotel dan restoran, Kota Mojokerto kontribusi terbesar diberikan oleh sektor perdagangan, hotel dan restoran, Kota Malang kontribusi terbesar diberikan oleh sektor perdagangan, hotel dan restoran, Kota Blitar kontribusi terbesar diberikan oleh sektor perdagangan, hotel dan restoran. Sedangkan kontribusi sektoral Propinsi Jawa Timur diperoleh dari sektor perdagangan, hotel dan restoran.

Hasil pola pertumbuhan ekonomi menggunakan alat analisis Tipologi Klassen di Kabupaten/Kota Koridor Utara Selatan Jawa Timur dapat disimpulkan bahwa Kabupaten/Kota yang termasuk kategori daerah cepat maju dan tumbuh adalah Kota Surabaya dan Kota Mojokerto. Daerah yang termasuk kategori maju tertekan adalah Kabupaten Gresik, sidoarjo, dan Kota Malang. Daerah yang 
termasuk kategori berkembang cepat adalah Kabupaten Pasuruan, Blitar, Kota Batu, Pasuruan, Blitar. Daerah yang termasuk kategori relatif terbelakang adalah Kabupaten Mojokerto, Kabupaten Malang.

\section{DAFTAR PUSTAKA}

Arifin Z. 2009. Kesenjangan dan Konvergensi Ekonomi Antar Kabupaten Pada Empat Koridor Di Propinsi Jawa Timur. Naskah Publikasi. UMM.

Arsyad, Lincolin. 1999. Ekonomi Pembangunan; Edisi Keempat. PB STIE YKPN. Yogyakarta.

Arsyad, Lincolin. 2004. Ekonomi Pembangunan; Edisi Keempat. Bagian Penerbit Sekolah Tinggi Ilmu Ekonomi Yogyakarta.

Boediono. 1981. Teori Pertumbuhan

Ekonomi. PB Fakultas Ekonomi UGM. Yogyakarta.

Badan Pusat Statistik. 2010. Produk Domestik Regional Bruto Kabupaten Malang. h. 92.

Badan Pusat Statistik. 2005-2009. Produk Domestik Regional Bruto. Kabupaten/Kota Se Jawa Timur.
Kunarjo. 1997. Perencanaan dan Pembiayaan Pembangunan; Edisi ketiga. UI Pres. Jakarta.

Kuncoro, Mudrajad. 2002. Analisis Spasial dan Regional. AMP YKPN. Yogyakarta.

Sjafrizal. 1997. Pertumbuhan Ekonomi dan Ketimpangan Regional Wilayah Indonesia Bagian Barat. Prisma, LP3ES No.3 Tahun XXVI. Jakarta.

Sukirno Sadono. 2006. Ekonomi Pembangunan: Proses, Masalah, dan Dasar Kebijakan. Kencana. Jakarta.

Suparmoko M. 2001. Ekonomi Publik Untuk Keuangan dan Pembangunan Daerah; Edisi Pertama. Andi. Yogyakarta.

Suryana. 2000. Ekonomi Pembangunan: Problematika dan Pendekatan. Salemba Empat. Jakarta.

Tarigan, Robinson. 2005. Ekonomi Regional Teori dan Aplikasi: Edisi Revisi. PT. Bumi Aksara. Jakarta.

Todaro, Maichel P. 2000. Pembangunan Ekonomi 1; Edisi Kelima. PT. Bumi Aksara. Jakarta. 